DOI https://doi.org/10.36059/978-966-397-113-1/90-120

\title{
THE IMPROVEMENT OF LEGAL REGULATION OF YOUTH JOB PLACEMENT IN UKRAINE
}

\section{Gubarev S. V.}

\section{INTRODUCTION}

The Constitution of Ukraine defines a socio-economic right as one of the most important human rights. It is not possible to ensure both dignity and existence of human personality without these rights; all other rights lose their sense to some extent without them. The central place belongs to the right to labor and its objective precondition such as the right to job placement.

In view of recent changes in our country, the development of conception for our state development where a modern socio-economic situation would be reflected and, first of all, at labor market, is of great importance. The further improvement of legislation on job placement as well as practice of its implementation is essential political-legal task within the process of establishment of social and law-governed state in Ukraine. The creation of a new system should be based, first of all, on scientific comprehension of legal relations arising in this field, subject's legal status, their rights and obligations, taking into account the interests of the state.

Transition to market relations in the field of labor and employment accompanied by the processes of structural economy reformation leads to the formation of a fundamentally new model of socio-labor relations. Young people who are not ready enough to the modern realities of the labor market experience these processes to the most extent. The development of a mechanism for interaction of all participants in sociolabor relations (state, employers, local authorities, public organizations) in the field of stabilization of youth employment is an urgent and socially significant step under such conditions. In addition, the Ukraine-European Union Association Agreement opens up new market opportunities. The high standards of production that the EU can offer will stimulate national enterprises to upgrade production and improve working conditions. However, many Ukrainian companies not ready for a dynamic change will 
be forced to go, which will reduce the number of job places. Moreover, the already high level of labor migration of Ukrainians to the EU countries will increase. This will negatively affect the national labor market. That is why it is important to change the rules of the game not only at the legislative level, but also to understand the value orientations of young people in the field of labor.

Youth is a socio-demographic group, whose life is associated with the future of society. It is this group that is considered as a leading factor in the intellectual development of society, a source of innovation and creativity. The study of youth labor values will allow stimulating young people properly for further work, which influence the whole functioning of the society, it will allow showing possible problems for the state in regulating the social policy of youth, helping in reveal of the complex relations and interactions of people in society, possible problems, determining the best ways to overcome them.

Today, in Ukraine, a set of measures has been formed to ensure a balance of interests of the labor market participants, to promote employment of the population and protection against unemployment. However, it should be noted that this set of measures requires to be improved in the terms of the present time. Moreover, national legislation does not pay enough attention to the problems of youth. The scientific analysis of youth employment problems which would allow elaborating specific recommendations and proposals with the aim of their further normative consolidation is required.

\section{Value Orientations of Youth in the Field of Job Placement}

Sociologists often view emotionally coloring ideas and judgments of the individual about the importance of his work in general and its individual parts as labor values. The peculiarity of labor values is a characteristic level of awareness, they are reflected in the psyche in the form of a system of value orientations and are an important factor in the regulation of labor relations and behavior in the group, they determine the tendencies of development of both personality and group ${ }^{1}$.

Over the past decades, the proclaimed, approved and supported labor values of our society have undergone changes that in total allows asserting

\footnotetext{
${ }^{1}$ Герусова О. Ю. Місце трудових цінностей в системі ціннісних орієнтацій підприємців і молоді / О.Ю.Герусова, І.В.Шинкаренко // Актуальні проблеми економічного і соціального розвитку регіону. - Красноармійськ: КІІ ДонНТУ, 2011. - С. 59.
} 
that the formation of new labor ethics is in process. Work on duty has become a right.

Labor values are in close correlation with educational ones. Universities under the influence of external factors are transformed into economic corporations which are run as corporations, but corporations of a special kind: associated with the production and dissemination of knowledge not only in Ukraine but also around the world. Students act as clients of the corporation, buyers at the market of educational services offered by the university. As a result, young people, faced with the real difficulties of choosing and building their professional career, often balance between unrealistic claims and passivity, full of reluctance to seek anything, discouragement in their own powers ${ }^{2}$.

The most important directions for the development of modern high school are intellectualization of the educational process contents, introduction of new forms of learning, creating conditions for students, developing their creative abilities. Finally, all this should be reflected in the training of professionals who, under the market economy conditions, aggravation of the competition as the labor market will be able to solve the problem of job placement ${ }^{3}$.

Timely and reliable information about the interests and life values of youth allows not only building the learning process more effectively, but preventing possible negative consequences of the unresolved problems as well, for example, the job placement of students and graduates, responding to changing demands of society in a timely manner. Such information is provided by regular sociological research.

For the analysis of youth labor values, the European Values Study (EVS) database was used in our study. EVS is a large-scale interstate study of universal human values. The surveys are conducted in the form of a formal interview. An adult population (aged 18+) is interviewed. The samples are representative of the countries. The sample in Ukraine was 1507 people. The youth makes 502 people out of all.

In defining the youth, we took as the basis Article 1 of the Law of Ukraine "On Promotion of Social Formation and Development of Youth

\footnotetext{
2 Лов'як О.О. Бушинський С.В. Окремі аспекти судової практики щодо оплати праці у період реформування національного законодавства // Пріоритетні завдання та стратегії розвитку юриспруденції в Україні та у світовій науці : матеріали круглого столу (15 листопада 2016 р.) відп. ред.. I. C. Тімуш. - Дніпро: Середняк Т. К., 2016 - С. 34-38.

Губарєв С. В. Трудове право України, посібник для підготовки до іспитів // Дніпропетровськ: Середняк Т. К., 2015. -125 с.
} 
in Ukraine", which stipulates that youth is "citizens of Ukraine aged 14 to $35^{\prime \prime}$. In our case, we use a group of 18-35 years old.

The attitude of youth to work differs in answering questions about its importance. Work is very important in life for $72 \%$ of young men, while for women, this number is $59 \%$. However, if we talk about the importance of work in general, the difference will be reduced and makes $97 \%$ for men and $91 \%$ for women. At the same time, the importance of work decreases with an increase in family income. Thus, $72 \%$ of respondents who indicated a family income as low noted the importance of work in their lives. Among respondents, there are $67 \%$ with an average income: with a high income $-65 \%$. In addition, the value of work increases with an increase in the educational level of the respondent. For $97 \%$ of respondents with a higher level of education, work is important, with an average level $-92 \%$; with a low $-89 \%$. However, taking into account only the answer "very important", for all educational levels the indicator is the same $-66 \%$. This indicates that education preserves its main function of training for the future profession. Young people go to higher education because it is important for them to have work later.

In relation to labor values, then the most important for youth is the value of good salary taking the first place. It is slightly prevails in men. Most young people have difference in such values as "comfortable work hours", "long vacation" and "work with people". All these labor values are more important for women. This can be explained by the fact that women give more time to family and home matters, and therefore it is important for them that work and family do not interfere with each other. Regarding work with people, it is well-known that women are more social and like to communicate more than men. It is interesting that the value of "not very hard work" was noted more by young men. The less important were the values of the future style of the manager and the provision of social benefits. For women, more important values of "interesting work", "guarantee of a job place preservation" and "equal treatment of all employees". On the last two values one can judge the existence of sexism at the workplace. Young people have almost the same indicators for the rest of the values.

In addition, as a result of the analysis of respondents' responses, two main types of correlation between the expected remuneration and the

\footnotetext{
4 Закон України «Про сприяння соціальному становленню та розвитку молоді в Україні» / [Електронний ресурс] - Режим доступу: http://zakon3.rada.gov.ua/laws/show/2998-12
} 
planned expenses were revealed. The most widespread was the inverse correlation between expectations of high salary and readiness for labor dedication. This was reflected in the fact that the respondents who pointed out the importance of high salary and reliability of job place, highlighted at the same time the importance of long vacation, comfortable work schedule, lack of excessive pressure, but neglected such labor values as the opportunity to show initiative, achieve something, and get a responsible job. And, on the contrary, those who chose the initiative, success and responsibility did not attach great importance to high salaries and other values listed above. It was also found that respondents who gave high salary values a priority did not seek to communicate with people and bring benefit to society. In contrast, those who chose to communicate and bring benefit to people, as well as to avoid excessive pressure on work, did not mention their high salary values, career development opportunities, and job security. From this it can be concluded that people appreciate work either as a way of communication and service to society, or as an opportunity for a personal career.

The hierarchy of labor values of men and women is different (Table 1). Unfortunately, the active labor values of men and women remain on the last stages of the hierarchy.

Table 1

The hierarchy of labor values of young men and women

\begin{tabular}{|c|c|}
\hline Young men & Young women \\
\hline Good salary (98\%) & Good salary (95\%) \\
\hline Good working team (78\%) & Interesting job (80\%) \\
\hline Interesting job (74\%) & Good working team (77\%) \\
\hline $\begin{array}{c}\text { Work which allows building up new } \\
\text { professional skills (59\%) }\end{array}$ & Flexible working hours (65\%) \\
\hline $\begin{array}{c}\text { Guarantees for job place preservation } \\
(59 \%)\end{array}$ & $\begin{array}{c}\text { Guarantees for job place } \\
\text { preservation (65\%) }\end{array}$ \\
\hline Work that matches skills (58\%) & $\begin{array}{c}\text { Equal treatment of all employees } \\
(61 \%)\end{array}$ \\
\hline Ability to achieve something (57\%) & Work that matches skills (60) \\
\hline
\end{tabular}




\begin{tabular}{|c|c|}
\hline $\begin{array}{c}\text { Equal treatment of all employees } \\
(54 \%)\end{array}$ & $\begin{array}{c}\text { Work which allows building up new } \\
\text { professional skills (59\%) }\end{array}$ \\
\hline Flexible working hours (48\%) & Ability to achieve something (57\%) \\
\hline Opportunity to show initiative (47\%) & Long vacation (53\%) \\
\hline Long vacation (41\%) & $\begin{array}{c}\text { Opportunity to show initiative } \\
(45 \%)\end{array}$ \\
\hline $\begin{array}{c}\text { Opportunity to take part in important } \\
\text { decisions (40\%) }\end{array}$ & $\begin{array}{c}\text { Work with people (44\%) } \\
\text { Not really hard work (39\%) } \\
\text { important decisions (40\%) }\end{array}$ \\
\hline Work with people (35\%) & Responsible work (34\%) \\
\hline Responsible work (33\%) & Not really hard work (33\%) \\
\hline Socially useful work (26\%) & Socially useful work (27\%) \\
\hline
\end{tabular}

According to the study conducted among students, graduates and employers, more than half of the interviewed graduates reported that they planed to work in their specialty $(61 \%)$. The highest percentage of graduates devoted to their specialty was among the graduates of the economic (79\%) and legal (90\%) faculties. Another situation is in other specialties, especially among the graduates of physics faculty, where only $17 \%$ of the respondents plan to work in the specialty. Here, the highest percentage was of those who know for sure that they will not work in their specialty after graduation of the university (32\%).

These ways of solving the problems of own employment, which young people use, allow making a conclusion that there is a rather high level of their psychological adaptation to the realities of the labor market. This is manifested in readiness for full employment, as stated by $63 \%$, despite the fact that the majority of them were students of full time departments of higher educational institutions, who applied for part-time employment $-20 \%$, temporal (occasional) employment $-13 \%$, vacation employment $-4 \%$. Young people really appreciate the level of job payment in various sectors of the economy: $57 \%$ have demonstrated the desire to work in the private sector, $18 \%$ - in the state, $18 \%$ - spoke about 
a high level of salary as a criterion of choice, $7 \%$ - want to open their own business.

The terms of the job search on average were significantly lower than for the unemployed in general: $18 \%$ were looking for work less than one month, from 1 to 4 months $-51 \%$, from 4 to 6 months $-12 \%$, more than 6 months $-19 \%$ of those interviewed. Among the methods of finding a job, they give a preference to the help of relatives and acquaintances $-40 \%$, apply to the services of private employment agencies $-25 \%$; send $\mathrm{CV}$ to different organizations independently - 19\%, apply to the public employment service $-8 \%$, while trying to find work in other ways $-8 \%$ of those interviewed. It should be noted that $92 \%$ of the interviewed students and $89 \%$ of graduates believe that the university should have a job placement service.

Looking for help in finding a job, both students and graduates share the view that it is often not enough to have just a good education. Theoretical and practical skills of communication with the employer, appearance, knowledge of the psychological aspects of interviewing and the nuances of writing a $\mathrm{CV}$ became a precondition for successful employment. In this regard, a significant number of the interviewed students noted that they needed consultations on the state of the modern labor market $-46 \%$, career planning $-12 \%$, psychological aspects of interviewing $-15 \%, \mathrm{CV}$ writing $-12 \% .29 \%$ of the interviewed students expressed their desire to receive additional training (for example, studying foreign languages, working with the computer); $67 \%$ wanted to help them in finding a job. Graduates also require consultation on the labor market $40 \%$, career planning $-14 \%$, interviewing $-17 \%$, and CV writing $-11 \%$. Respondents-graduates noted the necessity for help in finding a job $(70 \%)$ and in obtaining additional training $(28 \%)$.

Evaluation of the future employment prospects does not look optimistic yet: only $22 \%$ of respondents know where they will work, $40 \%$ are in active job search, $15 \%$ do not see any prospects on the job market, and $23 \%$ of respondents hesitated to answer this question. A widelyspread belief that the majority of students, especially senior students, are working, is exaggeration. Among the interviewed students $73 \%$ of them do not work. Among the reasons why students do not work in parallel with training in the first place - the difficulties of combining education with work (36\%); the second - the lack of material necessity (22\%); 
further - the negative impact of work on the quality of education (13\%); $9 \%$ of respondents appreciate their free time more than work and salary, and $8 \%$ - unable to find a job.

Many working students (39\%) combine work with studying to gain experience in their specialty. It should be added that $9 \%$ of students in the process of work find the prospect of employment after graduation, 35\% of the interviewed students work to be independent of parental help. At the same time, $52 \%$ are satisfied with their work completely, partly $-35 \%$, completely dissatisfied $-13 \%$ of respondents.

Among the young people entering the labor market, every fourth person has no profession, and every seventh has no professional experience. For these reasons, young people receive denial of employment on average 1.4 times more often than the older age group (Table 2).

Table 2

The reasons for employers' refusal in employment

\begin{tabular}{|c|c|c|c|c|}
\hline \multicolumn{2}{|c|}{$\begin{array}{l}\text { Younger than } \\
35 \text { years old }\end{array}$} & \multirow{2}{*}{ Reasons } & \multicolumn{2}{|c|}{$\begin{array}{l}\text { Older than } \\
\text { 35years old }\end{array}$} \\
\hline$\%$ & Rating & & $\%$ & Rating \\
\hline 34,8 & 1 & Lack of work experience & 8,6 & 4 \\
\hline 25,8 & 2 & Young age & 0,5 & 8 \\
\hline 19,3 & 3 & $\begin{array}{c}\text { Not sufficient level of education, } \\
\text { qualification }\end{array}$ & 13,6 & 2 \\
\hline 13,6 & 4 & Lack of necessary abilities and skills & 4,3 & 5 \\
\hline 11,0 & 5 & Requirements to salary & 13,1 & 3 \\
\hline 6,8 & 6 & Presence of minor child & 2,9 & $6-7$ \\
\hline 3,8 & 7 & Health conditions & 19,2 & 1 \\
\hline 2,3 & 8 & $\begin{array}{l}\text { Lack of skills on how to behave during } \\
\text { interview with employer }\end{array}$ & 2,9 & $6-7$ \\
\hline
\end{tabular}

As a result of the study, it was found that representatives of enterprises and organizations highly appreciate on the scale from one to five the level of minimum requirements that allow admitting a person to 
work, in particular, the requirements are as follows: on the theoretical and practical training of a young specialist (4.4 points); on the ability to make a decision independently (4.5 points); on the ability to communicate with people ( 4.5 points); on the ability to formulate a task and find a way to its solution (4.6 points). The highest requirements for graduates in relation to all of these parameters are established by banks. The requirements of commercial firms and private enterprises are also high, although slightly lower. The level of requirements for graduates from the state budget organizations is even lower. This is especially true of the practical training of a young specialist. Priority is given to the requirements for theoretical and practical training of graduates. Socio-demographic characteristics of graduates are important. Such a characteristic as age occupies the 5th place; graduate's gender - 6th place, with preference given to men; the marital status has 9th place, and the work is more often given to the married (and this requirement applies primarily to men). At the same time, the requirements for the orientation of a young specialist to professional and career growth are not significant.

Almost all employers negatively evaluate the quality of young workers, such as the lack of skills in working life and building relationships in the working team, instability of behavior, unnecessary emotionality, that is all that indicates the social immaturity of a person, the inadequate level of its socialization. However, it is in this particular case that the strongest influence of stereotypes on the mandatory presence of this kind of qualities is observed in all young workers without exception. The large scale and stability of the influence of such stereotypes leads to a discriminatory attitude towards the youth at the labor market. At the same time, it is obvious that the socialization of a person in society, although associated with age, takes place in certain people individually. The phenomena of infantilism and social immaturity can persist in a person until the end of his or her working life, and can be overcome at an early age, in the stage of professional training and formation. The competent construction of human resources policy in the organization involves the development of special programs that allow young professionals to adapt to the new role of hired employee and member of the working team ${ }^{5}$.

\footnotetext{
5 Губарєв С. В. Трудове право України, посібник для підготовки до іспитів // Дніпропетровськ: Середняк Т. К., 2015. - 125 с.
} 
The discrepancy of employer's ideas with the real characteristics of young people entering the labor market is combined with hardly ever justified ideas of youth about ways of adaptation in the field of labor and employment. This is manifested in the choice of profession, and in the future - in determining the prospects of own employment.

The results of the study, described in the article by O. Drozhanova "Value-motivational factors of the attitude to the labor of employees of industrial enterprises", indicate that the thoughts of employees on the importance of work for them, although insignificant, but differ depending on age, and persons who has not reached the age of 30 years are the most pragmatic. Among young employees, in comparison with older employees (46 or more), there are 1.3 times more people who consider labor as a means of earning money, and twice less of people who agree with labor judgments as self-value irrespective of earnings. Such differences can be explained not only by age characteristics, but also by the effect of sociocultural changes in society, which younger age cohort found at the stage of socialization. As an additional indicator of value attitude to work, orientation towards unemployment was used. In general, every fifth respondent $(21 \%)$ expressed the desire to leave paid employment, another $18 \%$ could not make a conclusion ${ }^{6}$. Moreover, the younger and more educated the employee is, the higher his readiness to change the company, the more he believes that his earnings are lower than in other companies ${ }^{7}$.

The research, described by L. Bevzenko in her book "The Lifestyles of Transitional Society", suggests that youth is more critical about the moral values of modern society and believes that for the sake of money, people can do almost everything. It is interesting that the statement "for the sake of big money people are able to work from morning to late evening" and "for the sake of big money people are able to take any job, only to be well paid" are the only statements in the age group of "up to 30 years" which has not the highest rate. That is, young people have a certain stereotype that people are ready for everything for money, except for individual and exhausting work. Young people perceive wealth as such that is dropping out of the sky.

\footnotetext{
6 Дрожанова О. Ціннісно-мотиваційні чинники ставлення до праці робітників промислових підприємств / О. Дрожанова // Соціологія: теорія, методи, маркетинг. - 2007. - №4. - С. 92.

Лов'як О.О. Бушинський С.В. Окремі аспекти судової практики щодо оплати праці у період реформування національного законодавства // Пріоритетні завдання та стратегії розвитку юриспруденції в Україні та у світовій науці : матеріали круглого столу (15 листопада 2016 р.) відп. ред.. I. С. Тімуш. - Дніпро: Середняк Т.К., 2016 - С. 34-38.
} 
The research "The youth of Ukraine: Lifestyle and Value Orientations" has shown that in the hierarchy of life priorities of young people in Ukraine, the values associated with professional employment have a rather high place. $72 \%$ of young men and $67 \%$ of young women indicated that "good work and professional employment" are "essential". Especially, there are a lot of young people for whom "essential" values are such values that are closely linked with economic activity and labor activity values like "economic independence" (69\% of men and 59\% of women) and material well-being (79\% of men and $74 \%$ women).

The value of good work is important for young people, but it still plays a bigger role for men, while women note the value of education and knowledge more (49\% of men and $57 \%$ of women). For men, the value of "high official and civil status" is important as well (40\% of men and 31\% of women). Young people almost equally appreciate the importance of such a value as "the possibility of development, implementation of abilities" ( $45 \%$ both for men and women). Most working young people are satisfied with their current job, evaluating it at 7 points out of 10 . At the primary work, young people mainly work as hired employees (47\%), and only $2 \%$ were employers and business owners. $45 \%$ of young men and $36 \%$ of young women would like to become entrepreneurs, but they are disturbed by different circumstances, $33 \%$ and $45 \%$ do not want to do it, respectively.

The results of the survey give an opportunity to form an opinion about the extent of prevalence of the knowledge, skills and abilities in the youth environment that are now highly valued in the employee: skills of working with computer technologies, knowledge of foreign languages, driving, skills to work with office equipment. Contrary to popular opinion, the degree of prevalence of possession of certain innovative skills (and especially - in foreign languages) is still rather low even in the youth environment in Ukraine. Thus, among the respondents, only 37\% knew English well (33\% of men and $41 \%$ of women). Knowledge of other foreign languages did not exceed $6 \%$. The results of the analysis in relation to differences in the degree of prevalence of certain innovative skills possession by young people's age groups are also quite natural and quite predictable. The largest percentage of computer skills and knowledge of foreign languages is in the age group of 15-19 years old; 
driving - age group of 30-34 years; work with office equipment - age group of 20-24 years.

Thus, rather high labor orientations are typical of young people in Ukraine. During the transformation period in the country there was a significant diversification of domains and forms of young people employment, which increased the importance of vocational training for them as well as became an incentive to increase personal competitiveness at the labor market. It is for young people that the issue of the employment quality obtains a fundamental nature, since they have, in general, the highest demands-requests to the level of salary, the nature of professional employment, working conditions, etc. It should be recognized that part of Ukrainian youth is sometimes characterized by the presence of unreasonable ambitions, which, unfortunately, are not supported by either a sufficient educational-professional level or work experience. Young people often choose jobs not by interest, but only by salary amount, at the same time they want everything at once: a good position and a high salary that is why the demands of employers and young professionals often do not match. Moreover, due to the weakening of the labor value-ethical basis and the ineffectiveness of institutional foundations of the youth labor socialization under the modern conditions, the choice of the field of young people's activity not only often contradict to the obtained specialty, but sometimes goes beyond the legal norms.

As for the basic labor values of Ukrainian youth, one can conclude that work plays an essential role in young person's life. However, there are some differences within this group. So, for men, for young people with higher education and for young people with a low level of family income, work is more important. Each of these points can be explained through social roles, economic situation and social problems in the country. In all groups of young people, the value of good salary has the highest rates of importance, and active labor values remain on the last stages of the hierarchy. However, other aspects of work may differ. Young women in their work focus on the value of convenience, sociality and reliability of work more men. At the same time, men appreciate lack of tension, interest and initiative more. Active post-material labor values are more typical of young people with high education and high family income. Materialistic and convenience values are important for young people with an average level of education and income. For young people 
with a low level of education and income, equality and usefulness in work are important values.

Comparing to other age groups, young people are characterized by a longer period of future working capacity, which may be required by organizations that implement a particular business strategy to different extents. Entrepreneurial strategy usually does not motivate the administration to form a permanent labor team; this strategy is often focused on the short existence of the organization itself. In this case, a long period of future working capacity of an employee is more likely to disturb his labor motivation. A young employee who seeks professional development and career growth will have to limit his aspirations to a certain level of remuneration. The strategy of changing the course that forces employees to temporarily lose their own interests in the interests of the organization may be unacceptable for young people due to a number of other specific features (high level of labor and social mobility, ideal thoughts about working life). This quality of young employees is of the greatest interest for continuously functioning organizations, with a clearly differentiated human resources policy for different categories and groups of employees, in which career planning has an important place. Accordingly, the young specialists themselves are interested in finding employment in such organizations.

\section{Reformation of the Field of Normative-Legal Regulation of Youth Job Placement in the Context of Euro-integration Processes}

Today, the main attention in the developed countries around the world is given to measures aimed at intensifying, on the one hand, the work of employment services, and on the other, the efforts of the unemployed to find a new job. The latter includes a significant liberalization of the concept of suitable work, in connection with the activity of seeking work with the amount of assistance, material incentives for the unemployed, recruited in the short term.

A social welfare system for unemployment, which involves the use of various mechanisms and means of providing benefits to the unemployed, has a special place among the measures aimed at employment provision and protection against unemployment in the developed countries.

It is important to provide young people with reliable and fair channels for job search as well. For example, graduates of British 
universities find work through advertisements in newspapers and magazines $-41 \%$, through recruitment agencies $-30 \%$, through direct contact with an employer - $12 \%$ and only 9\% - through friends and acquaintances $^{8}$. At the same time in Australia, every fourth-year student knows where he or she will work in the future.

Considering the provisions of international legal acts in this field, the key element of national employment and job placement systems should be the provision of full employment of people that is provision of opportunity of job receipt for everyone who is ready to go to work. In addition, such work should be as productive as possible and chosen on the basis of a free choice. Measures aimed at full employment and protection against unemployment include: the creation and proper operation of free employment services; creation and proper functioning of the welfare system in case of unemployment; creation and proper functioning of the system of professional orientation, training and retraining; creation of new jobs; assistance in matters of employment for certain categories of people who are not competitive at the labor market (especially young employees).

An important aspect of reformation is the change in the educational area. One of important provisions of the Bologna Process is the orientation of higher education institutions to the final result: the knowledge of graduates should be implemented in practice for the benefit of the entire Europe. The problem of reforms also consists in the fact that it is necessary to make changes not only in laws on education, but also in a number of accompanying documents (for example, the Law of Ukraine "On Higher Education", etc.). The Ukrainian state has been trying to solve the employment problems of educational institution graduates for a long time. Over the past six years, the state order for the training of bachelors increased from 96.4 to 127.0 thousand (by 24\%), and the scope of masters training - by 3.5 times.

The first and decisive criterion for the effectiveness of higher education and science activities in general and a specific higher educational institution in particular is the demand for specialists at the labor market. In our opinion, useful and fruitful may be the signing of the following: agreements between the Ministry of Education and Science of Ukraine and the Federation of Employers of Ukraine, etc.

\footnotetext{
${ }^{8}$ Пашинян И. А. Работа и трудоустройство в восприятии студентов / И. А. Пашинян // Социс 2010. - № 1. - C. 130.
} 
A number of experts and leaders of the educational sector made a suggestion on the ranking of higher education institutions and the introduction of elements of a particular tender for the placement of government orders, taking into account the efficiency of graduates' employment as the final result of cooperation with employers.

National education does not meet the requirements of personality formation, civil society, democratization, openness and transparency in full. The format of the educational process due to certain systemic difficulties is not oriented to the comprehensive development of personality, satisfaction of his or her needs, provision of demands of society and the labor market by competitive, competent and responsible specialists. The level of interaction between education and social partners does not contribute to solving this problem. At present there is no public responsibility for the quality of education of those who are involved in its provision, effective integration processes. Employers mostly do not participate in the formation of content of education and provision of highquality vocational and practical training of youth. There is no constant monitoring of the education quality at all levels with the participation of students, parents, representatives of non-governmental organizations, rating assessment of the educational institution activities and their publishing.

The system of financing of education requires to be substantially improved, providing objective control in the format of "cost effectiveness - efficiency - results". At the same time, it should be taken into account that not only quantitative indicators of financing play a role in fulfilling the strategic tasks of Ukrainian society development. The structure of investments in education and skilled management in the field is not less important. Education is an extremely profitable branch of the economy, not so much with direct payments for tuition, but from the economic benefits that qualified professionals will bring with their work.

As for the number of students of higher educational institutions, Ukraine keeps up with the developed countries. The main problem is precisely in the quality of education and the provision of graduates with good work. Otherwise, the transition to European standards of education can become a stimulator of "brain drain" from Ukraine, lowering its intellectual potential. A proper remuneration for skilled labor should be an important step to prevent this. 
The indicators that characterize a share of salary from GDP and a cost of production remain low, inappropriate to the world practice. In GDP, in recent years the share of salary was $45 \%$, while in the countries of the European Union, on average, it was $65 \%$. In the cost of production, the share of labor costs is around 14\%, while in the most EU countries this number is $30-35 \%$. One should concern about the discrepancy in salary of employees with the same level of qualification in public and private sectors. The salaries in the public sector are by $20 \%$ lower than in private one. It is differently in the developed countries. For example, in the United States, labor costs in the public sector per one man-hour are 1.5 times higher than in private?

Therefore, first of all, in the context of the European integration processes, Ukraine should identify the employment model that best suits the Ukrainian realities, and then adequately adapt it to the national conditions, by agreeing and completing all the gaps in national legislation.

\section{The Ways of Improvement in Legal Regulation of Job Placement in Ukraine}

The regulation of the youth employment process should be considered as a targeted influence on the behavior of the subjects of the labor market youth segment in order to ensure the maximum possible employment of young people, which will improve the quality of their life and create the basis for sustainable development of the country's economy. The regulation of the employment process for young people at the labor market should take place through both generally accepted and specific methods and based on information, institutional, scientific and regulatory framework. At the same time, the said regulation should be aimed at providing such guarantees in the field of employment and job placement for young citizens as guarantees aimed at: ensuring a free choice of work; protection of employees' labor rights during the establishment and termination of labor relations; reduction of unemployment and provision of the unemployed with funds for life; special guarantees for employees with reduced competitiveness at the

\footnotetext{
9 Освітня політика в контексті євроінтеграції / [Електронний ресурс] - Режим доступу: http://old.niss.gov.ua/book/Zdioruk2/07.pdf
} 
labor market (in particular, young people who enter the labor market for the first time $)^{10}$.

The state should become the most important intermediary and partner in terms of employment at the youth labor market under the present conditions, since under the conditions of economic crisis, aggravating the state of the labor market and its youth segment, the rest of employment subjects are not able alone to solve the problem of providing the youth with workplaces effectively. It is due to state regulation that the labor market becomes an integral part of a market economy, ensures the normal functioning of the economy, social stability of society and the reproduction of labor forces. At the same time, the state itself should take care of the development of social stability and youth protection, adjust the employment policy, review and update the legislative framework, timely finance state employment programs, develop a system of incentives and benefits for regions with low youth unemployment ${ }^{11}$.

Lack of priority state policy in relation to the youth labor market has led to a number of negative phenomena in the process of its formation. Therefore, the crisis processes fully reflected the situation of young people as the least protected category. Unresolved problems of youth employment lead to the rise of unemployment and reduction of living standards, the spread of passive, unregulated and destructive behaviors, they encourage to external labor migration, causing psychological changes (loss of motivation to work, change in the structure of value orientations, and decline of prestigious legal employment).

Implementation of the state policy in the field of youth employment should be carried out systematically and consistently at all three stages of the youth's entry into the labor market: when choosing a profession and shaping professional plans; vocational training and professional adaptation $^{12}$. In recent years, the employment of young people - graduates of higher educational establishments - requires special attention, as their share in the number of the unemployed is almost $20 \%$.

In order to radically improve the normative legal regulation of employment and job placement, it is necessary to combine all norms of

\footnotetext{
${ }^{10}$ Безусий В. В. Правове регулювання працевлаштування в Україні: автореф. дис. на здобуття наук. ступеня канд. юр. наук; спец. 12.00.05 / В. В. Безусий. - Харків, 2007. - С. 5.

${ }_{11}$ Федорова А. А. Реалізація кадрового потенціалу молоді на ринку праці України / А. А. Федорова, Т. В. Карпенко // Бізнес Інформ. - 2011. - № 11. - С. 110.

12 Губарєв С. В. Трудове право України, посібник для підготовки до іспитів // Дніпропетровськ: Середняк Т. К., 2015. - 125 с.
} 
the normative legal acts in the field of employment and job placement after their qualitative processing into one codified act with the title of the Code of Laws On Employment of the Population of Ukraine or the Labor Code of Ukraine and to provide there a book named "Relations in the filed of Employment and Job Placement", which fully incorporates the revised normative legal acts on employment and job placement. Such document will help to identify the regularity and properties of the right to job placement as an independent legal phenomenon, improve the system of employment agencies, define their rights and responsibilities, and outline the structure of this right and its legal regulation.

In 2013 already the draft Labor Code of Ukraine was designed, which was never adopted, and then in general it was withdrawn ${ }^{13}$. As for the advantages of the draft Labor Code over the current Code, then the first one is its title, since the Labor Code is concise and meaningful title, and most important, it is similar to other titles of the codes such as civil, criminal, land, etc. The draft exceeds the current Code on the number of articles, which allows solving a large number of problems more efficiently, and regulating social relations better. The draft contains many chapters not included in the current code.

However, there are many shortcomings in the draft Labor Code. First of all, it is stated that the subject of labor regulation are collective labor disputes, and there is no corresponding chapter for their regulation. Although the draft has a book number sixth devoted to collective labor relations, but it does not contain norms for resolving disputes between the subjects of relations. Nevertheless, continuation of the work on the Labor Code is crucial.

In order to ensure the proper regulation of public relations in the state, the exercise and protection of the rights, freedoms and legitimate interests of citizens, it is important that the lawmaker, firstly, gives definitions of the terms which he applies in the normative legal acts, and secondly, these definitions should be clear, logical and unambiguous.

There is a necessity to improve the normative legal framework of employment and job placement in Ukraine in a certain way, in particular:

- To stipulate clause 3 of Article 1 of the Law of Ukraine "On Employment of the Population" in the following wording: "In Ukraine, the employed population includes citizens of Ukraine who:

\footnotetext{
13 Проект Трудового кодексу України / [Електронний ресурс] - Режим доступу: http://w1.c1.rada.gov.ua/pls/zweb2/webproc4_1?pf3511=46746
} 
a) Work on the terms of a labor agreement (contract) at enterprises, institutions and organizations, irrespective of the forms of ownership, in international and foreign organizations in Ukraine and abroad, for natural persons;

b) Self-employed persons, who are entrepreneurs, persons engaged in creative activity, members of cooperatives, farmers and members of their families involved in production, lawyers, private notaries, auditors;

c) Serve in the alternative (non-military) service in the Armed Forces of Ukraine, the Security Service of Ukraine, the State Border Guard Service of Ukraine, internal troops, the Civil Defense Forces of Ukraine, the internal affairs bodies of Ukraine, other military formations established in accordance with the legislation of Ukraine, alternative (nonmilitary) service;

d) Undergo professional training, retraining and advanced training in the classroom; study secondary schools and higher educational establishments on full time basis;

e) Engaged in the execution of works and provision of services on the basis of civil law contracts.

Citizens of other states and stateless persons residing or temporarily staying at the territory of Ukraine on legal grounds and carry out functions not related to the provision of the activities of embassies, missions, consulates and trade missions of foreign states also belong to the employed persons;

- To define clearly in the Law of Ukraine "On employment of the Population" who is recognized as partly unemployed, who can not be recognized as partly unemployed, as well as to develop a procedure for registration of partly unemployed;

- To include transport accessibility in the list of obligatory criteria of suitable work;

- To increase the quota of workplaces established by the Law of Ukraine "On employment of the population" up to $10 \%$, as well as to establish a mandatory quota for enterprises and organizations for the employment of young specialists.

In view of the high percentage of unregistered unemployment in Ukraine, the State employment service needs to conduct an active advocacy work on the appropriateness and positive nature of being registered with the State employment service, but the most important 
thing is that the State employment service should organize its work in such way that young people will really believe that this state body does everything possible to meet the needs of every person in the field of employment.

Today, in order to solve the problems of employment in the state, it is necessary to actively involve trade unions and other public organizations, as well as enterprises, institutions and organizations, together with state and local self-government bodies.

Among the economic factors, which should be necessary taken into account in the formation of a youth employment policy, structural changes play an important role. Predictable shifts in the structure of economy should be accompanied by processes of employment optimization and should be aimed at increasing its efficiency. Among many reasons for shortages of personnel is the low motivation of youth to work, poor working conditions and pay, lack of guaranteed social package, etc. Young people do not hurry up to occupy vacancies in enterprises with old equipment, poor working conditions. This is the reason for shortage of personnel of many enterprises due to the excess supply at the labor market ${ }^{14}$.

The degree of the labor force competitiveness at the labor market depends primarily on the level of vocational education - the higher it is, the higher the level of economic activity and employment, and the lower the informal employment and unemployment. At the same time, unemployed persons with high educational status experience the greatest difficulties in finding a job ${ }^{15}$.

According to the branch structure of youth employment, the current labor market is characterized by its uneven distribution. If on average one out of four employed people is a young person, then in health care, education and science - every third, in trade - more than $28 \%$. In the financial and managerial field, the process of rejuvenation of personnel is traced. In industry and construction, the share of young employees, by contrast, is 2-3 times lower than the average. The desire of young people to work in transport, agriculture, housing and communal services and

\footnotetext{
${ }^{14}$ Натолока О.О. Основні проблеми працевлаштування молоді в Україні / [Електронний ресурс] Режим доступу: http://www.kbuapa.kharkov.ua/e-book/conf/2013-2/doc/2/22.pdf

${ }_{15}$ Натолока О.О. Основні проблеми працевлаштування молоді в Україні / [Електронний ресурс] Режим доступу: http://www.kbuapa.kharkov.ua/e-book/conf/2013-2/doc/2/22.pdf
} 
consumer services is the lowest ${ }^{16}$. The desire of young people to work in transport, agriculture, housing and communal services and consumer services is the lowest ${ }^{17}$.

The success of job placement depends on many factors: economic (demand for work forces, salary, opportunities to be employed in accordance with a previously acquired profession or after retraining); socio-demographic (age, gender, health status, marital status, the presence of children and dependents); demographic and economic (level of education, professional qualification, availability of work experience, financial capacity and availability of additional sources of earnings, etc.). However, even if these positive factors are present, the success of employment is not guaranteed if they are not based on sociopsychological factors determining the attitude of a person towards his or her own unemployment and orientation of his or her efforts to overcome the problem situation, the willingness to mobilize own efforts to succeed $^{18}$.

Taking into account that the solution to the job placement problem depends primarily on the person himself or herself: his or her attitude to the situation, intentions and the manifestation of personal activity special attention is paid to the measures aimed at forming the socioprofessional and psychological characteristics in the unemployed person that contribute to the successful adaptation of a person to the changing external circumstances, increasing his or her own competitiveness at the labor market and mobilizing own potential in order to successfully overcome the problem ${ }^{19}$.

It is necessary to solve the problem of employment increasing and to approach its solution comprehensively by way of ${ }^{20}$ :

1) Strengthening of state regulation of the educational services market for the training of young specialists differentiating it by branches of knowledge; forecasting of demand for youth labor by occupations and

\footnotetext{
${ }^{16}$ Натолока О.О. Основні проблеми працевлаштування молоді в Україні / [Електронний ресурс] Режим доступу: http://www.kbuapa.kharkov.ua/e-book/conf/2013-2/doc/2/22.pdf

${ }^{17}$ Натолока О.О. Основні проблеми працевлаштування молоді в Україні / [Електронний ресурс] Режим доступу: http://www.kbuapa.kharkov.ua/e-book/conf/2013-2/doc/2/22.pdf

18 Авдеєв Л. Г. Роль людського фактора в успішному працевлаштуванні / [Електронний ресурс] Режим доступу: http://ipk-dszu.kiev.ua/journal/2011-4.pdf

${ }^{19}$ Авдеєв Л. Г. Роль людського фактора в успішному працевлаштуванні / [Електронний ресурс] Режим доступу: http://ipk-dszu.kiev.ua/journal/2011-4.pdf

${ }^{20}$ Натолока O.O. Основні проблеми працевлаштування молоді в Україні / [Електронний ресурс] Режим доступу: http://www.kbuapa.kharkov.ua/e-book/conf/2013-2/doc/2/22.pdf
} 
planning of the qualification and educational structure of its proposal should be included in its competence;

2) Promoting the limited youth employment in the informal sector of the economy, as well as preventing discrimination of young people at the labor market and increase in unemployment; local self-government bodies should actively monitor the situation of young people at the regional labor market;

3) Granting greater powers to local governments in solving such problems as: development of labor market infrastructure; encouraging employers to create new jobs; stimulation of youth entrepreneurship; ensuring the active interaction of scientific centers with regional state administrations in developing strategies for the development of youth segments of regional labor markets;

4) Improvement of educational activity of modern educational institutions in order to ensure the quality of providing educational services.

Evaluating the overall situation at the labor market requires a qualitative, rather than purely quantitative approach. The task is not only or not so much in providing graduates with the latest information on available jobs and applications from organizations, but also in providing them with the opportunity to directly establish relations with these organizations, to learn about the requirements for specialists, the interests of "customers", as well as the situation at the labor market in general, which will help in making informed choices. And, certainly, the issue of distribution should be addressed in advance, in the period of work practice, although the student takes the final decision in the last year of studying.

In recent years, the forms of student self-organization have begun to develop in the field of work: firms and organizations are being created, engaged in the employment of students and graduates of higher educational institutions, gathering and disseminating information among them about possible places and proposed working conditions, organizing "Career Days" and other forms of contacts between students and employers $^{21}$.

One way of solving the youth job placement problem is to use such form of facilitation of exercise of the right to work for students who are

\footnotetext{
21 Герчиков В.И. Феномен работающего студента ВУЗа / В. И. Герчиков // Социологические исследования. - 2009. - С. 91.
} 
studying at the expense of enterprises, and for employers in their choice of highly skilled personnel as the target contractual training of specialists with higher and secondary specialized education. In order to improve the legal regulation of target contractual training of specialists, these issues should be regulated in the employment law, where it is necessary to clearly determine: the content of contracts to be concluded; the order of their conclusion; the question of the responsibility of employers and educational institutions for violating contract terms, in particular, for refuse in taking graduates to work, to determine the grounds and procedure for reimbursement by a student who does not comply with the terms of the contract in favor of the employer or the educational institution of the expenses incurred in connection with student's training, to establish the possibility of concluding fixed-term labor contracts with persons trained within the target contract preparation.

For young people adaptation who are looking for work for the first time to the modern labor market conditions, it is necessary to take special measures aimed at schoolchildren and students, namely: formation of motivation of youth for employment; informing young people about the state of the labor market, the conditions for its functioning, and the most demanded jobs and specialties; familiarization with the legislation on labor and employment (in schools, lyceums, universities, at courses, etc.); vocational guidance and professional counseling work in schools and vocational schools; illustration of the variety of ways of possible person's self-realization; formation of active job search and diligence skills in young people; assisting in planning a career, promoting a conscious choice of young people in the form of employment, type of profession; the organization of temporary workplaces for youth and adolescents with the purpose of acquiring labor skills, work experience in the profession.

According to experts ${ }^{22}$ an effective measure to promote youth job placement is to establish control over the employment of young graduates whose need have previously been declared; the initiation and development of integrated programs for the organization of work practice in educational institutions and the possibility of fixing such practice in the work book as part of work experience. The employment problem for young people who are particularly in need of social protection (disabled people, parents with many children, etc.) should be provided by methods

\footnotetext{
${ }^{22}$ Балакірєва О. М. Проблеми працевлаштування та міграційні орієнтації молоді / О. М. Балакірєва, О. В. Валькована // Економічний простір. - 2009. - № 2. - С. 89.
} 
of a targeted, highly specialized approach designed to address the individual characteristics of this category of young people, including the quotation of workplaces. It is necessary to support the opinion of many experts who believe that the process of developing a flexible labor market and effective youth employment should be supported by government measures to reduce standard forms of employment and promote new flexible forms of employment of young employees ${ }^{23}$.

In the modern conditions a distance employment can be one of these forms. The distance employment is defined as a non-standard form of employment, involving flexible social and labor relations between the employee and the employer directly in the virtual environment using information and communication technologies. The non-standard nature of this employment form is conditioned by the unsteadiness of the workplace, irregular working hours, instability and flexibility of social and labor relations. The virtual environment of distance employment involves widespread use of information and communication technologies, work through information networks, work at home and in special centers spatially remote from the company's main office ${ }^{24}$.

The use of distance employment is possible in these forms. Firstly, it can be the main form of employment in the organization, primarily for creative professions: artists, programmers, designers, copywriters, webmasters, photographers, journalists, editors, proofreaders, translators, etc. Secondly, it is a possibility of remote work for individual employees of the company ${ }^{25}$. At the same time, despite the outlined advantages of distance employment, its use may be subject to certain limitations. Firstly, work at home is characterized by a decrease in the number of visual and oral communication, and for a young person with limited social contacts, this form of employment may be ineffective. Secondly, the possibility of applying a distant form of employment depends on scrupulosity and experience of each individual employee to a certain extent. As a result, due to low self-organization, the increase in the working time to perform the necessary task at the expense of free time is possible. Thirdly, experts point out to almost complete shadowing of distance work in Ukraine,

\footnotetext{
${ }^{23}$ Пірон І. В. Сучасна державна політика зайнятості населення в Україні / I. В. Пірон // Форум права. - 2010. - № 1. - С. 303.

24 Красномовець В. А. Характеристика трудових відносин в умовах дистанційної зайнятості / В. А. Красномовець // Соціально-трудові відносини: теорія та практика. - 2011. - № 2. - С. 86-91.

25 Красномовець В. А. Характеристика трудових відносин в умовах дистанційної зайнятості / В. А. Красномовець // Соціально-трудові відносини: теорія та практика. - 2011. - № 2. - С. 88.
} 
which has definitely a negative impact on the labor market and the economy of the country.

One of the priority ways for promoting young people employment should be the creation of basis for youth development entrepreneurship. V. Yaroshenko believes that the choice of a person of the employment area (public or private sector) and its form largely depends on age, gender, and profession.

In his opinion, it is the youth that the most inclined to entrepreneurial activity. For some, this is due to the opportunity to increase their incomes, for others, including young specialists, it is the opportunity to show their individuality, to satisfy the need for creativity ${ }^{26}$. To solve the problem of developing alternative forms of employment such as private entrepreneurship, it is necessary to distinguish the following measures: creation of a developed infrastructure for supporting entrepreneurial initiative by providing cash subsidies to citizens in the organization of their own business; determination of the priority areas of youth employment; coordination of work for all state bodies in this area, taking into account the necessity to promote self-employment, first of all, off those citizens whose professional skills and abilities remain nondemanded at the labor market; development of regional programs for promoting youth micro-business, in particular its financial and credit regulation.

Youth employment is also impossible without an effective state employment policy, which should be aimed at ensuring the flexibility of the youth labor market, increasing the mobility of employees, regulating the hidden unemployment segment, legalizing informal and illegal employment, and stimulating youth work activity and labor demand. However, ensuring employment will depend on the growth of production output and investment aimed at creating new jobs. Therefore, an important area of the state policy in the employment field is the provision of interconnection of measures in economic development, fiscal and tax policies.

It should also be noted that effective regulation of the young people employment is impossible without reliable forecasts regarding the prospective change in demand and supply on the youth labor market, as well as improvement of information provision of this process. National

\footnotetext{
26 Ярошенко В. Проблема конкурентоспроможності національного ринку праці України / В. Ярошенко // Україна: аспекти праці. - 2008. - № 6. - С. 15.
} 
monitoring of youth employment needs improvement because it does not give an objective evaluation of the youth labor market in many aspects. Thus, the surveys on the population economic activity do not reflect the information about young people having worked without labor contracts, under the difficult or harmful conditions, part-time or with an extended working day, performed jobs below their qualification ${ }^{27}$. For the completeness of the youth labor market characteristics, the proportion of young people who are not working and not studying should be considered, too. This indicator is calculated in the United Kingdom, China, Japan and Korea, and covers economically inactive young people who are not working and studying after receiving compulsory general secondary education due to illness, disability, the need for family responsibilities or unemployment.

In addition, there is no statistics on the average length of employment of educational institution graduates in the context of knowledge branches in Ukraine. This indicator reflects the average duration of employment in the first job after the completion of vocational education. At the same time, it is an indicator of the demand for knowledge by the market, that is, an informative factor in the formation of government orders for specialists and masters by knowledge branches. Monitoring the duration of job placement is very important, as the increase in the duration of forced unemployment leads to a loss of knowledge and skills, disbelief, the spread of labor apathy, etc. Moreover, the scientists proved that for graduates who early in their working life face a long period of unemployment it is more likely to experience deterioration in the quality of working life through shifting periods of low-paid employment. According to experts, effective basis for effective regulation of youth employment should be immediate provision of government authorities with accurate and complete information on the amount of current and prospective additional needs of enterprises for employees by professional qualification structure, on the one hand and professional qualification structure of labor supply, on the other hand. The shortage of relevant information concerning the state of the labor market segments makes its effective regulation impossible ${ }^{28}$.

\footnotetext{
27 Губарєв С. В. Робочий час: правовий погляд // Проблеми правової реформи в трудовому законодавстві Україні: матеріали круглого столу. - К., 2015 - С. 7-12.

28 Корецька С. О. Удосконалення системи інформаційного забезпечення кількісно-якісного оцінювання трудових ресурсів / С. О. Корецька // Держава та регіони. - 2014. - № 2.- С. 79.
} 
Therefore, in order to solve problems in the youth employment field, it is necessary to eliminate not their consequences, but the causes of their occurrence and existence. The legislative and normative acts regulating the employment of young people of different categories do not adequately take into account the socio-economic opportunities of Ukraine, its socioeconomic development. To solve these problems it is necessary: to create specific student enterprises for the job placement of minors in time-free from education; promote the creation of youth small enterprises and cooperatives; to create the departments at higher educational institutions or at employment services for the promotion of youth job placement. At the same time, improvement of legislative and normative framework is one of the main comprehensive measures for the implementation of state youth policy, namely: improvement of legal preconditions for effective work in the main areas of youth policy; definition of the mechanism of observance of the legislative norms at the local level; definition and consolidation of functions and powers, rights and obligations of subjects of legal relations in the field of youth policy. So, it can be stated that the legislation does not sufficiently define the responsibility of employers for refusing to employ young citizens; there are no normative documents on the economic stimulation of employers who create jobs for the relevant categories of youth above the established quota. It is necessary to have a perfect mechanism for regulating the employment of different categories of youth, which would take into account the financial, social and economic opportunities of the state, region and enterprises.

It is essential to create conditions facilitating the attraction and consolidation of young professionals in production, namely: decent salary and its timely payment, the availability of social guarantees to the employee, the possibility of job promotion, the solution of housing issues, the initiative of students of secondary and students of initial vocational education during the work practice at enterprises. It is necessary to recognize the field of youth employment as a priority component of the state social policy, since young people are the largest strategic resource of the country.

At the present stage of development, the main areas of the state employment policy regarding the employment of young people should be expansion of the scope of labor application, the formation of a favorable business environment, and increase in social protection of citizens. The 
state employment policy should be focused on creating new productive jobs to the full extent. It is the job creation policy in Ukraine that is one of the least effective. Even under the conditions of financial crisis, the policy of creating new jobs could be realized through the use of indirect economic instruments such as tax relief, the development of small and medium-sized businesses, attraction of foreign investment, and financial incentives for companies in case of employment of young unemployed people by them.

\section{CONCLUSIONS}

Summarizing all the abovementioned we can say there should be the following priority areas of regulation of youth job placement processes at the labor market such as the increase in youth competitiveness at the labor market; development of employment competences; expansion of flexible forms of employment; stimulation of self-employment; balance of labor markets and educational services, improvement of information provision of job placement processes, development of collective-contractual methods of youth employment regulation. The practical implementation of the developed conceptual framework for regulating the employment of young people at the labor market will increase the employment rate of young people and the quality of life of such socio-demographic group representatives, as well as facilitate the creation of the basis for sustainable development of economy in the country.

\section{SUMMARY}

The author has formulated and recommended the main ways of improving the legal regulation of youth job placement in Ukraine for practical application based on their value orientations. The developed methodology will give the opportunity to use the experience gained for further improvement of this topic.

\section{REFERENCES}

1. Декларація від 15 груд. 1992 р. № 2859-XII Про загальні засади державної молодіжної політики в Україні / [Електронний pecypc] - Режим доступу: www.rada.gov.ua

2. Загальна декларація прав людини / [Електронний ресурс] - Режим доступу: http://zakon1.rada.gov.ua/laws/show/995_015 
3. Закон України Про вищу освіту / [Електронний ресурс] - Режим доступу: http://zakon2.rada.gov.ua/laws/show/1556-18/page6

4. Закон України Про внесення змін до деяких законів України щодо зменшення впливу світової фінансової кризи на сферу зайнятості населення / [Електронний ресурс] - Режим доступу: http://zakon4.rada.gov.ua/laws/show/799-17

5. Закон України Про державні соціальні стандарти та державні соціальні гарантії / [Електронний ресурс] - Режим доступу: http://zakon2.rada.gov.ua/laws/show/2017-14

6. Закон України Про загальнообов'язкове державне соціальне страхування на випадок безробіття / [Електронний ресурс] Режим доступу: http://zakon2.rada.gov.ua/laws/show/1533-14

7. Закон України Про зайнятість населення / [Електронний ресурс] Режим доступу: http://zakon4.rada.gov.ua/laws/show/5067-17

8. Закон України Про молодіжні та дитячі громадські організації / [Електронний ресурс] - Режим доступу: http://zakon4.rada.gov.ua/laws/show/281-14

9. Закон України Про оплату праці / [Електронний ресурс] - Режим доступу:

http://zakon1.rada.gov.ua/laws/show/108/95$\% \mathrm{D} 0 \% \mathrm{~B} 2 \% \mathrm{D} 1 \% 80$

10.Закон України «Про сприяння соціальному становленню та розвитку молоді в Україні» / [Електронний ресурс] - Режим доступу: http://zakon3.rada.gov.ua/laws/show/2998-12

11.Кодекс законів про працю / [Електронний ресурс] - Режим доступу: http://zakon4.rada.gov.ua/laws/show/322-08

12.Проект Трудового кодексу України / [Електронний ресурс] Режим доступу: http://w1.c1.rada.gov.ua/pls/zweb2/webproc4_1? pf3511=46746

13. Авдеєв Л. Г. Роль людського фактора в успішному працевлаштуванні / [Електронний ресурс] - Режим доступу: http://ipk-dszu.kiev.ua/journal/2011-4.pdf

14.Балакірєва О. М. Проблеми працевлаштування та міграційні орієнтації молоді / О. М. Балакірєва, О. В. Валькована // Економічний простір. - 2009. - № 2. - С. 76-91.

15. Безусий В. В. Правове регулювання працевлаштування в Україні: автореф. дис. на здобуття наук. ступеня канд. юр. наук; спец. 12.00 .05 / В. В. Безусий. - Харків, 2007. - 20 с. 
16.Болотіна Н.Б. Трудове право України: підручник / Н. Б. Болотіна. - К.: Вікар, 2014. - 725 с.

17.Волкова О. В. Розвиток телероботи та інтернет-професій на віртуальному ринку праці XXI ст. / О. В. Волкова // Науковий Вісник Полтавського університету споживчої кооперації України. - 2008. - № 2. Частина 1. - С. 51-54.

18. Герасимчук В. І. Проблеми трансформації зайнятості і ринку праці України / В. І. Герасимчук. - К.: ТОВ «ПРИНТ ЕКСПРЕС», 2011. $-503 \mathrm{c}$.

19.Герусова О. Ю. Місце трудових цінностей в системі ціннісних орієнтацій підприємців і молоді / О.Ю.Герусова, I. В. Шинкаренко // Актуальні проблеми економічного i соціального розвитку регіону. - Красноармійськ: КІІ ДонНТУ, 2011. $-363 \mathrm{c}$.

20.Герчиков В.И. Феномен работающего студента ВУЗа / В. И. Герчиков // Социологические исследования. - 2009. C. 87-94.

21.Гончарова Н. В. О рынке труда выпускников ВУЗов / [Електронний ресурс] - Режим доступу: http://ecsocman.hse.ru/ data/972/870/1231/011.GONCHAROVA.pdf

22. Губарєв С. В. Трудове право України, посібник для підготовки до іспитів // Дніпропетровськ: Середняк Т. К., 2015. - 125 с.

23. Губарєв С. В. Робочий час: правовий погляд // Проблеми правової реформи в трудовому законодавстві Україні: матеріали круглого столу. - К., 2015 - С. 7-12.

24.Губарєв С. В. Гарантії прав працівників на охорону праці // Сучасне правотворення: питання теорії та практики: матеріали всеукраїнської науково-практичної конференції. - К., 2016 C. $72-77$.

25.Губарєв С. В. Правовий погляд на працю жінок // Сучасні тенденції в юридичній науці України та зарубіжних країн: матеріали міжнародної науково-практичної конференції (27 жовтня 2017 р.) / відп. ред. С. В. Губарєв, І. С. Тімуш. - К., ФОП Кандиба Т. П., 2017. - 148 с. - С.18-23.

26. Дрожанова О. Ціннісно-мотиваційні чинники ставлення до праці робітників промислових підприємств / О. Дрожанова // Соціологія: теорія, методи, маркетинг. - 2007. - № 4. - С. 83-97. 
27.Корецька С. О. Удосконалення системи інформаційного забезпечення кількісно-якісного оцінювання трудових ресурсів / С. О. Корецька // Держава та регіони. - 2014. - № 2.- С. 76-81.

28. Красномовець В. А. Характеристика трудових відносин в умовах дистанційної зайнятості / В. А. Красномовець // Соціальнотрудові відносини: теорія та практика. - 2011. - № 2. - С. 86-91.

29. Лов'як О.О. Бушинський С.В. Окремі аспекти судової практики щодо оплати праці у період реформування національного законодавства // Пріоритетні завдання та стратегії розвитку юриспруденції в Україні та у світовій науці : матеріали круглого столу (15 листопада 2016 р.) відп. ред. І. С. Тімуш. - Дніпро: Середняк Т.К., 2016 - С. 34-38.

30.Натолока О.О. Основні проблеми працевлаштування молоді в Україні / [Електронний ресурс] - Режим доступу: http://www.kbuapa.kharkov.ua/e-book/conf/2013-2/doc/2/22.pdf

31.Пашинян И. А. Работа и трудоустройство в восприятии студентов / И. А. Пашинян // Социс - 2010. - № 1. - С. 130-133.

32. Пірон I. В. Сучасна державна політика зайнятості населення в Україні / I. В. Пірон // Форум права. - 2010. - № 1. - С. 300-305.

33. Федорова А. А. Реалізація кадрового потенціалу молоді на ринку праці України / А. А. Федорова, Т. В. Карпенко // Бізнес Інформ. 2011. - № 11. - С. 109-111.

34. Ярошенко В. Проблема конкурентоспроможності національного ринку праці України / В. Ярошенко // Україна: аспекти праці. 2008. - № 6. - C. 10-17.

35.Освітня політика в контексті євроінтеграції / [Електронний pecypc] - Режим доступу: http://old.niss.gov.ua/book/Zdioruk2/ 07.pdf 